\title{
ОСОБЛИВОСТІ КЛІНІЧНОГО ПЕРЕБІГУ ЗАЛІЗОДЕФІЦИТНОЇ АНЕМІЇ У ЖІНОК 40-55 РОКІВ
}

\author{
С.А. Гусєва ${ }^{1}$, Я.Б. Савченко ${ }^{2}$
}

\author{
1 Українська військово-медична академія, м. Київ, Україна \\ ${ }^{2}$ Національний військово-медичний клінічний центр «ГВКГ», м. Київ, Україна
}

\begin{abstract}
Вступ. Дефіцит заліза (ДЗ) є серйозною проблемою у жінок віком 40-55 років. В цей період відбувається варіації гормональних рівнів, порушення менструального циклу з ризиком виникнення тяжкої крововтрати. Крім того, жінки цієї вікової групи часто ведуть нездоровий спосіб життя, з наступним розвитком порушень, що призводять до змін у фізичному і психічному станах.

Мета роботи. Дослідити причини розвитку ЗДА у жінок, які знаходилися під спостереженням у клініці гематології Національного військового медичного клінічного центру «Головний військовий клінічний госпіталь» МО України і визначити фактори ризику розвитку анемії та ії корекції.

Матеріали та методи. У статті надані дані європейських досліджень про високий ризик розвитку дефіциту заліза/залізодефіцитної анемії (ДЗ/ЗДА) у жінок віком 40-55 років. Проведений аналіз обстеження та лікування 109 жінок, котрі знаходилися під спостереженням у клініці гематології Національного військово-медичному клінічному центрі «ГВКГ» (м. Київ) з 2015 по 2019 роки.

Результати. Узагальнено сучасні наукові європейські дослідження щодо ризику розвитку ДЗ/ЗДА у жінок віком 40-55 років. Проведено аналіз причин розвитку ЗД/ЗДА за результатами обстеження та лікування жінок, котрі знаходилися під спостереженням у клініці гематології Національного військовомедичному клінічному центрі «ГВКГ» (м. Київ) з 2015 по 2019 роки. Виділено найбільш часті причини розвитку ЗД/ЗДА: рясні менструальні крововтрати, запальні процеси в органах шлунково-кишкового тракту, зниження вживання м'ясних продуктів, прийоми антикоагулянтів, порушення дієти з метою схуднення, що в цілому складає 75\% серед можливих причин.
\end{abstract}

Висновки. За даними європейських досліджень виявлено високий ризик розвитку ДЗ/ЗДА у жінок віком 40-55 років при цьому клінічні прояви ЗДА у жінок віком 40-55 років є проблемою суспільної охорони здоров'я, оскільки призводить не тільки до зниження працездатності, але й до зниження якості життя жінок. Результати проведених досліджень свідчать про багатофакторну структуру причин розвитку ДЗ у жінок віком 40-55 років, головними з яких є рясні менструальні крововтрати (21,1\%), запальні процеси в органах шлунково-кишкового тракту (19,26\%), зниження вживання м'ясних продуктів $(13,76 \%)$, прийоми антикоагулянтів $(10,1 \%)$. Показано, що визначення факторів ризику розвитку анемії $і$ корекції цих негативних проявів за допомогою препаратів заліза є актуальним завданням для лікаря. терапія.

Ключові слова: жінки 40-55 років, дефіцит заліза, залізодефіцитна анемія, причини розвитку,

Вступ. Дефіцит заліза (ДЗ) є найбільш розповсюдженим у світі захворюванням. У всьому світі залізодефіцитна анемія (ЗДА) зареєстрована у 500 млн. людей. У країнах Європи ЗДА страждають 10-12\% жінок і 3-8\% чоловіків. У $30 \%$ жінок репродуктивного віку спостерігається Д3 $[1,2]$, що значно погіршує якість їхнього життя [3].

Серед лікарів існує думка про те, що ЗДА частіше розвивається під час вагітності. Більшість із них не усвідомлюють, що ДЗ є серйозною проблемою у жінок віком 40-55 років також. Відомо, що в період між 40 і 55 роками, який включає пременопаузу, періменопаузу i постменопаузу, значно погіршується здоров'я та якість життя жінок [4], оскільки в цей період спостерігаються варіації гормональних рівнів, порушення менструального циклу з підвищеним ризиком тяжкої крововтрати [2]. Крім того, жінки цієї вікової групи часто ведуть нездоровий спосіб життя, який пов'язаний з порушенням дієти 3 метою втрати ваги, відсутністю фізичних вправ, або 3 інтенсивними фізичними навантаженнями. Ці порушення призводять до змін у фізичному i психічному станах, сприяють виникненню i розвитку втомлюваності [ 5].

Мета роботи: дослідити причини розвитку ЗДА у жінок, які знаходилися під спостереженням у клініці гематології Національного військового медичного клінічного центру «Головний військовий клінічний госпіталь» МО України і визначити фактори ризику розвитку анемії та її корекції.

Матеріали та методи. На 15-му Всесвітньому Конгресі Міжнародного товариства менопаузи, у вересні 2016 року в Празі, відбувся симпозіум під назвою «Жінки 40-55 років: клінічні думки і якість життя» (Women 40-55 Years Old: Clinical Consideration and Quality of Life)», який був присвячений цій 
клінічній та суспільній проблемі. Були визначені дві мети симпозіуму: з'ясувати, чому в цей перехідний період в житті жінки потрібний контроль рівня ризику ДЗ і як лікування ДЗ може поліпшити якість життя жінок. За матеріалами цього симпозіуму в 2017 році був опублікований огляд A. Firquet i співавторів [6]. Особливий інтерес представляє опис клінічного випадку. Пацієнтка Х.,45 років звернулася до лікарягінеколога з скаргами на загальну слабкість, нічну пітливість, рясні менструальні крововтрати. На запитання лікаря-гінеколога про можливі причини порушення самопочуття пацієнтка відповіла: «...я думаю, що старію. Все змінюється. Я почуваю себе дуже втомленою. Незважаючи на втомлюваність, я ще намагаюсь займатися фізичними вправами. Я дотримуюсь дуже строгої дієти, іноді, відчуваю підвищення температури тіла, а зранку прокидаюсь спітнілою. Я завжди була позитивною, тепер я почуваю себе пригніченою, і мене більше не цікавить секс. А потім я стікаю кров'ю - це так незручно. Місячні тривають довго і нерегулярно. Це мене дуже турбує».

Ця більшість симптомів може наштовхнути лікаря на відповіді до кількох питань, так як багато із скарг цієї пацієнтки свідчать про наявність клімактеричного синдрому, синдрому хронічної втомлюваності, сексуальної дисфункції, депресії, неправильного способу життя, патологічних маткових кровотеч. Однак, тільки лабораторні дослідження вирішують діагностичні сумніви на користь ЗДА: зниження рівня гемоглобіну (Hb) (110 г/л) і сироваткового феритину (15 мг/л), при якій спостерігаються більшість із симптомів, котрі спостерігалися у пацієнтки X. [7].

Проведений аналіз обстеження та лікування 109 жінок, котрі знаходилися під спостереженням у клініці гематології Національного військово-медичному клінічному центрі «ГВКГ» (м. Київ) з 2015 по 2019 роки.

Результати дослідження та їх обговорення. Добре відомо, що клінічні прояви ЗДА обумовлені наявністю анемічного синдрому і ДЗ (сидеропенічний синдром). Як правило, ДЗ розвивається поступово, а появі анемічного синдрому передує тривалий період сидеропенії. Вираженість клінічних симптомів при ЗДА залежить не тільки від глибини ДЗ і тяжкості анемії, але і від ступеня адаптації організму до залізодефіцитного стану.
Анемічний синдром при ДЗ проявляється відомими і неспецифічними для анемії любого походження симптомами з боку майже всіх органів і систем. Клінічними проявами ДЗ/ЗДА $\epsilon$ слабкість, підвищена втомлюваність, зниження фізичної і розумової активності, психо-емоційні коливання. Типовими скаргами пацієнтів 3 ЗДА $\epsilon$ потемніння перед очами при зміні положення тіла, запаморочення, непритомні стани, головний біль, шум у вухах, відчуття «пульсації» в голові або в усьому тілі, біль в ділянці серця, задишка і серцебиття при фізичних навантаженнях, підвищена чутливість до інфекції $[8,9]$.

Незважаючи на велику кількість клінічних проявів, найбільш чутливими $\mathrm{i}$ значущими скаргами, які впливають на якість життя у 14-33 \% пацієнтів, $\epsilon$ слабкість і зниження когнітивної функції [10]. Ці клінічні прояви при ЗДА і ДЗ є великою проблемою суспільної охорони здоров'я. Тим не менше, при адекватній діагностиці причин слабкості і зниження когнітивної функції, можлива корекція цих негативних проявів $[5,11]$.

Клінічні прояви сидеропенічного синдрому розвиваються внаслідок тканинного Д3, який призводить до порушення нормального функціонування різних органів і систем, в результаті зниження активності внутрішньоклітинних ферментів, які вмістять залізо - цитохромів [3, 8]. Недостатня кількість міоглобіну та дихальних ферментів обумовлює значну м'язову слабкість.

Пізнавальна (когнітивна) функція, яка вміщує здібності до аналізу, уваги, пам'яті, навчання у жінок репродуктивного віку залежить від метаболізму заліза в організмі [6]. Такі показники когнітивних процесів, як увага, пам'ять і здібність до навчання, у жінок віком 45 - 50 років з ДЗ до початку менопаузи були статистично вірогідно меншими, ніж у жінок аналогічного віку з нормальним рівнем заліза [6]. Підтвердженням цього стала робота L.E. Murray-Kolb [12], результати якої свідчать про нормалізацію когнітивної функції у жінок після феротерапії.

Деякі сидеропенічні симптоми $\epsilon$ характерними тільки для ЗДА. Це спотворення смаку (pica chlorotica): бажання споживати незвичайні продукти, такі як земля, глина, пісок, сирі продукти, лід, а також захоплення гострою, соленою, кислою або пряною їжею. У частини пацієнток виникає спотворення нюху: захоплення запахом бензину, ацетону, землі 
після дощу, лако-фарбових виробів, сирого дерева та інш.

При тяжкій ЗДА можуть виникати набряки на нижніх кінцівках, особливо на стопах. Гіпосидероз шкіри призводить до їі сухості та потоншенню, порушенню цілісності епидермісу. В кутках роту виникають виразки внаслідок потоншення шкіри 3 запальним валиком (ангулярний хейліт). За рахунок тривалого ДЗ у тканинах спостерігається атрофія сосочків язика: червоний язик, у більш тяжких випадках - 3 ділянками почервоніння неправильної форми «географічний язик». Сухість шкіри супроводжується появою тріщин на стопах. Типовим клінічним проявом гіпосидерозу $є$ ламкість нігтів, їх поперечна смугастість, іноді нігті приймають ложкоподібну, ввігнуту форму (койлоніхії). Дефіцит заліза супроводжується підвищеним випадінням волосся та їх ламкістю [13].

Зважаючи те, що дані про розповсюдженість ДЗ/ЗДА у жінок віком 40-45 років (країн Європи) відсутні, був проведений інтернет-аналіз по епідеміології розповсюдженості та факторів ризику виникнення ДЗ/ЗДА у жінок цієї вікової групи [6]. Результати епідеміологічних досліджень, які були проведені в розвинутих країнах Європи, показали, що у жінок 40-55 років часто спостерігаються як ДЗ, так і ЗДА $[6,9]$. Саме ці дані спонукали вчених Європи до визначення факторів ризику розвитку ДЗ/ЗДА [6].

Низьке споживання заліза при порушенні дієти з метою втрати ваги відмічено у більшості жінок в пременопаузальному періоді [14]. Згідно сучасних рекомендацій [14], жінка, яка має менструацію, повинна споживати біля 18 мг дієтичного заліза на добу. В дослідженні SUVIMAX було встановлено, що 93\% жінок віком 40-55 років 3 метою схуднення виключають із дієти м'ясо, що призводить до зниження споживання дієтичного заліза до 12 мг на добу. Інші дієти, яких дотримуються жінки цієї вікової категорії, також сприяють значному зменшенню заліза. Так, R.W. Wojciak [15] оказав, що обмеження харчування протягом двох днів (менше 200 ккал/добу протягом 7 тижнів призводить до зменшення концентрації феритину і заліза на $28 \%$ і $8 \%$ відповідно.

Аліментарна недостатність заліза сприяє виникненню ЗДА. Харчові продукти, як тваринного, так і рослинного походження вмістять залізо у вигляді гему, 2- і 3-валентних неорганічних іонів. Головним чином, 3 продуктів

тваринного

походження всмоктується неорганічне $\mathrm{Fe}^{2+}$ і залізо, яке входить в склад гему. Тому, у пацієнтів 3 низьким рівнем життя і у вегетаріанців існує високий ризик розвитку ЗДА. Ця причина розвитку анемії, особливо $є$ характерною, для груп с низьким соціально-економічним статусом [14].

При дотриманні вегетаріанської дієти також існує значний ризик розвитку ДЗ. Відомо, що ця дієта забезпечує організм людини великою кількістю негемового 3валентного заліза [14], яке погано всмоктується (1-5\%). В той час гемове залізо, яке зустрічається, в продуктах тваринного походження всмоктується на 25\% [16]. A. Waldmann і співавтори [17] встановили, що у $40 \%$ жінок віком до 50 років, які знаходяться на вегетаріанскій дієті, мають ДЗ.

Підвищена крововтрата відіграє ключову роль в патогенезі ДЗ/ЗДА у жінок 4055 років. Рясні менструальні крововтрати (менорагії) (тривалість більш 7 днів і/або крововтрата більш 80 мл) зареєстровані у 11 $13 \%$ населення у цілому, у $25 \%$ жінок віком 40 49 років і у 9,2\% жінок віком 50-55 років [16 18]. За час нормальної менструації жінка втрачає близько 25-30 мл крові, що відповідає втраті 12,5-15 мг заліза. В цій клінічній ситуації для лікаря край важливо з'ясувати наявність у жінок таких крововтрат. Більшість жінок приховують цей факт за різними причинами: деякі в силу свого виховання рахують, що ці менструації $\epsilon$ «незручною» темою для розмови, іншим пацієнткам важко кількісно оцінити менструальну крововтрату [19]. Згідно з рекомендаціями [19 - 22], терапевтичні дії повинні бути спрямовані на поліпшення якості життя жінок (корекція анемії), а не на корекцію менструальних крововтрат. Із рахунком базальних втрат крові, добова потреба жінки, яка менструює, складає 2,4 заліза, але тільки біля 2\% жінок мають адекватне відтворення цих втрат крові

Крім менструальних крововтрат важливу роль у виникненні ДЗ/ЗДА відіграють внутрішньоматкові спірали, наявність яких може спричиняти підвищені втрати крові 3 поступовим знищенням депо заліза у 28\% жінок [23]. Носові, ясневі крововтрати, а також множинні підшкірні екхимози, іноді, призводять до розвитку анемії при тромбоцитопатіях, тромбоцитопеніях та інших геморагічних діатезах. 
Іншим джерелом крововтрат у жінок 40-55 років можуть бути захворювання шлунково-кишкового тракту (ШКТ). B.T. Green i D.C. Rockey [24] при обстеженні жінок віком до менопаузи із ЗДА спостерігали, що у $82 \%$ із них були нормальні менструальні крововтрати, але у 25\% були симптоми захворювань ШКТ, при цьому, у 41\% з них виявлено наявність крові у калі. Причиною ЗДА можуть бути безсимптомні пухлини шлунку і кишечника. Злоякісні пухлини ШКТ, особливо часто, виявляють у жінок після менопаузи (10-17 \%).

Хронічні втрати крові при захворюваннях ШКТ, зазвичай, характеризуються невеликим об'ємом крові и часто проходять непомітно для пацієнтів. При цьому лікарі різних фахів не завжди адекватно дають оцінку причин розвитку ЗДА. Незначні за об'ємом, але відносно тривалі крововтрати, призводять до зменшення запасів заліза 3 наступним розвитком ДЗ і ЗДА. Встановлено, що в 1 мл крові, яка втрачається, вміститься 0,5 мг заліза. При добової крововтраті в 10 мл крові втрата заліза складає 5 мг. Таким чином, навіть при втраті такого невеликого об'єму крові спостерігається поступове зменшення запасів заліза. Слід зазначити, що при багатьох захворюваннях ШКТ, ДЗ розвивається не тільки внаслідок хронічних втрат крові, але і в результаті порушення його всмоктування.

До розвитку ЗДА призводять, іноді, хронічні крововтрати, які обумовлені паразитарною інвазією (Ancylostoma duodenale, Necator americanus, Schistosoma, Trichuris trichiura та інші.). Втрати крові, при цьому, можуть коливатися від 2 до 100 мл, а втрати заліза - 0,8-1,2 мг кожну добу. ЗДА може розвиватися при наявності Helicobacter pylori внаслідок хронічної окультної крововтрати, конкурентної втрати заліза бактеріями, зниження концентрації аскорбінової кислоти і підвищення активності гепсидину $[25,26]$.

Застосування препаратів інгібіторів протонної помпи призводить до порушення абсорбції заліза [27]. При тривалому застосуванні антикоагулянтів, аспірину, нестероїдних протизапальних препаратів (НПЗП), можуть виникати приховані крововтрати із наступним розвитком Д3 [24]. До розвитку ЗДА можуть призводити кровопускання у пацієнтів зі справжньою поліцитемією і вторинними еритроцитозами, проведення гемодіализу при хронічній нирковій недостатності, часті забори крові для досліджень. Можливий розвиток ЗДА при нерегламентованому донорстві крові.
Порушення всмоктування заліза $\epsilon$ частою причиною його дефіциту. Залізо у продуктах харчування їжі знаходиться, переважно, у 3-валентній формі, і, тільки, після переходу його у 2-валентну форму відбувається всмоктування заліза. На всмоктування заліза у кишечнику впливають: соляна кислота шлункового соку, сік 12-палої кишки, вітамин С, швидкість проходження харчової кашиці по тонкому кишечнику, потреба організму в залізі (при Д3 всмоктування його $\epsilon$ більшим, ніж при нормальному або високому вмісті заліза) [7]. Саме тому, ДЗ внаслідок порушення процесів всмоктування розвивається у жінок, які перенесли тотальну гастректомію, субтотальну резекцію шлунка або ваготомію 3 гастректомією. Патогенез ЗДА при цих станах $\epsilon$ пов'язаним зі зменшенням секреції шлунком соляної кислоти і швидким транзитом харчової кашиці по кишечнику після втрати резервуарної функції шлунку та виключення активних ділянок всмоктування заліза, які знаходяться в 12-палій кишці.

Синдром мальабсорбції спричинений порушенням всмоктування через слизову оболонку тонкого кишечника одного або декількох поживних сполук. Найбільш частою причиною мальабсорбції є целіакія, резекція шлунка, колонізація Helicobacter pylori, рідко резекція кишківник або надмірний бактериальний ріст [28]. Запальні захворювання кишечника призводять до порушення функції клітин кишечника [28]. Тому, у 80\% пацієнток з анемією і запальними захворюваннями кишечника розвивається ДЗ внаслідок порушення абсорбції заліза i крововтрат [29, 30].

Встановлено, що ЗДА при запальних захворюваннях кишечника

$\epsilon$ багатофакторною. В більшості випадків, у таких пацієнтів має місце комбінація анемії хронічного захворювання (АХЗ) (анемія запалення) і ЗДА. Під час запального процесу, прозапальні цитокини активують синтез гепсидина, який відповідає за секвестрацію заліза у внутрішньоклітинний феритин. Концентрація феритину в сироватці крові підвищується незалежно від статусу заліза, і це підвищення може маскувати Д3 [30]. В таких випадках для підтвердження запалення необхідне дослідження С-реактивного протеїну [28], концентрація котрого, звичайно, підвищена при наявності запалення [31]. 
Ожиріння, яке часто виникає у жінок 40-55 років, також $\epsilon$ фактором ризику розвитку ДЗ [28, 32 ], оскільки, при цьому спостерігається утримання заліза в ентероцитах і макрофагах. Підвищена потреба в залізі виникає у деяких жінок середнього віку, які турбуються про свою фігуру i починають інтенсивно займатися спортом. У жінок-спортсменок, які займаються бігом на довгих дистанціях, часто розвивається ДЗ внаслідок порушення дієти, підвищеної крововтрати (втрати заліза з потом, гемоліз еритроцитів, гематурія, шлунково-кишкові крововтрати) [33].

Нами проведено дослідження причини розвитку ЗДА у жінок 40-55 років, котрі знаходилися під спостереженням у клініці гематології Національного військового медичного клінічного центру «Головний військовий клінічний госпіталь» МО України 3 2015 по 2019 роки. Результати можливої причини розвитку ЗДА за даними анамнезу надані на рис. 1.

За нашими даними, найбільш частими причинами розвитку ЗДА у жінок 40-55 років виявилися рясні менструальні крововтрати, запальні процеси ШКТ, зниження вживання м'ясних продуктів і прийом антикоагулянтів.
Таким чином, дані літератури та власні дослідження свідчать про багатофакторність розвитку ДЗ/ЗДА. Проблема ДЗ залишається актуальною для охорони здоров'я не тільки для країн, які розвиваються, але і для країн Європи. Складність вирішення цієї проблеми полягає у тому, що симптом ДЗ/ЗДА $є$ неспецифічним. Саме тому багато хто із пацієнток не зовсім адекватно оцінюють їх, а іноді й випускають їх із виду, не повідомляють про них лікарю загальної практики або лікарю-гінекологу. Саме тому, задля перевірки основних факторів ризику європейськими експертами був запропонований контрольний список (табл. 1) у вигляді акроніму [6].

За наявністю хоч би одного позитивного тесту, який наведений в цій таблиці, у жінок 40-55 років існує ризик розвитку ДЗ/ЗДА. У таких випадках необхідне дослідження рівнів Нb і феритину.

Сучасні автоматизовані аналізатори дозволяють визначати характерні для ДЗ зміни еритроцитів: зменшення середнього вмісту Нb в еритроциті (МСН) (норма 28-35 пг) - гіпохромія і середнього об'єму еритроцитів (MCV) (норма 80-100 фл) - мікроцитоз. МСН є більш надійним показником, так як він $є$ менш залежним від впливу гемоаналізаторів.

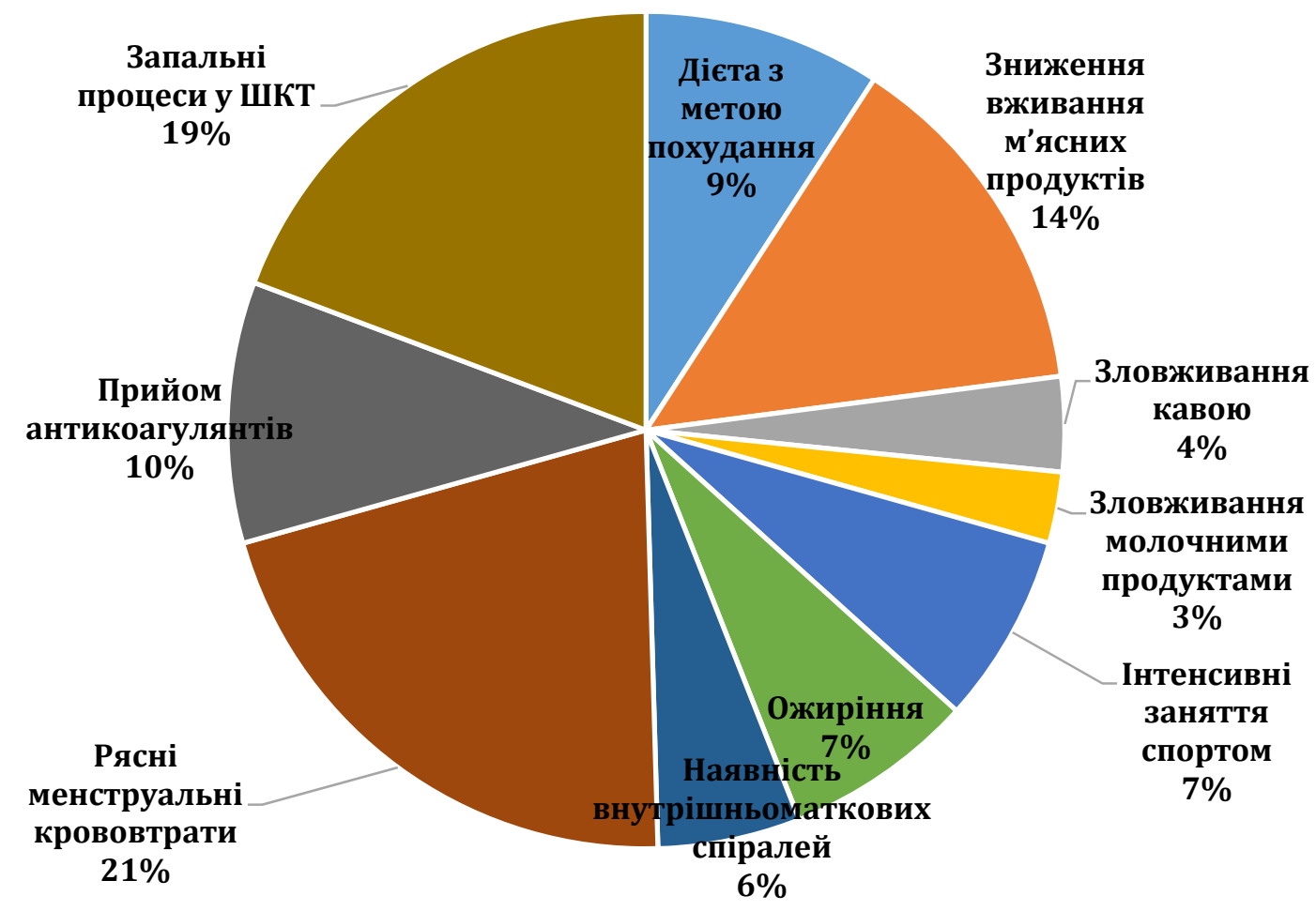

Рисунок 1. Причини розвитку ЗДА у жінок віком 40 -55 років. 
Контрольний список DEFICIT для виявлення факторів ризику дефіциту заліза у жінок середнього віку

\begin{tabular}{|l|l|}
\hline & \multicolumn{1}{|c|}{ Фактори ризику } \\
\hline D & $\begin{array}{l}\text { Diet - Дієта з метою схуднення, вегетаріанство, зниження вживання з їжею вітаміну C, } \\
\text { зловживання кавою, чаєм, молочними продуктами (Са }{ }^{2+} \text { ) }\end{array}$ \\
\hline E & Excessive sport - Інтенсивні заняття спортом \\
\hline F & Fatique - втомлюваність, слабкість та інші симптоми Д3 \\
\hline I & IUD - внутрішньоматкова спіраль або рясні менструальні крововтрати \\
\hline C & Celiac disease - Целіакія \\
\hline I & Inflammatory conditions - запальні процеси, ожиріння \\
\hline T & Anticoagulants - прийом антикоагулянтів, дезагрегантів, аспірину, НПЗП, донорство \\
\hline
\end{tabular}

Як мікроцитоз, так і гіпохромія - $€$ чутними показниками ДЗ при відсутності хронічних захворювань і супутнього дефіциту вітаміну $\mathrm{B}_{12}$ або фолієвої кислоти. Підвищений показник ширину розподілу еритроцитів (RDW) (норма 11-15 \%) часто вказує на супутній дефіцит вітаміну $\mathrm{B}_{12}$ або фолієвої кислоти [12].

Концентрація заліза сироватки звичайно $\epsilon$ зниженою, але може бути i нормальною (50-120 нг/дл або 9,0-21,5 мкмоль/л). Слід пом'ятати, що цей показник $\epsilon$ динамічним: коливання протягом доби складають до 10-20 \%. Концентрація заліза може також підвищуватися одразу після прийому препаратів які вміщують залізо.

Саме тому при визначенні справжнього рівня сироваткового заліза рекомендується протягом декількох днів утримуватися від прийому цих препаратів. Про наявність ДЗ можливо думати при зниженні сироваткового заліза менш 50-60 нг/дл (9,0-10,7 мкмоль/л) [7].

Важливим тестом, який дозволяє встановити ДЗ, $€$ вміст в сироватці крові феритину - білка, рівень якого відображає кількість запасів заліза в депо, і зниження рівня котрого $\epsilon$ найбільш чутливим i специфічним лабораторним признаком ДЗ. В нормі вміст феритину в сироватці крові коливається від 15 до 300 нг/л (33,7-674,1 пмоль/л), у дітей нижче, ніж у дорослих. У чоловіків рівень феритину $\epsilon$ вищим ніж у жінок до менопаузи. Критерієм ЗДА $\epsilon$ зниження рівня феритину менше 12-15 нг/л (або <27,0-33,7 пмоль/л) [20].

Інформативним маркером ДЗ $є$ рівень розчинних трансферинових рецепторов (sTfR), але, на даний час, цей показник ще широко не застосовується в клінічній практиці i нормативні показники рівня STfR ще не $\epsilon$ стандартизованими. При ЗДА цей показник $\epsilon$ вищим значень норми. Високу чутливість і специфічну значущість для діагностиці ЗДА має співвідношення рівня STfR до десятинного логарифму рівня феритину (в нормі менше 1). Для ЗДА є характерним підвищення цього показника вище 2,9 мг/л. При рівні феритину менше 20 нг/л ці показники не мають додаткової діагностичної значущості [12]. Одним із найбільш ранніх індикаторів недостатності заліза в КМ є підвищення рівня цинк-протопорфірину еритроцитів більш 80 нмоль/моль $\mathrm{Hb}$ [2].

Необхідно пом'ятати, що концентрація заліза може бути зниженою навіть при відсутності ДЗ. Це спостерігається при АХЗ внаслідок накопичення запасів заліза в макрофагах і блокування його виходу в кров. Концентрація заліза може підвищуватися при наявності супутніх запальних i хронічних захворювань. Рівень феритину може підвищуватись при хронічних запальних і не запальних захворюваннях, патології печінки або нирок, онкологічних захворюваннях або після прийому препаратів заліза.

Саме тому критерієм ЗДА, згідно рекомендацій експертів В03, прийняти такі показники:

- зниження величини MCV ( менше 80 фл);

-зниження концентрації Нb в еритроцитах (менше 29 пг);

-зниженні рівня феритину < 12-15 нг/л.

Контроль анемії за допомогою препаратів заліза у жінок 40-55 років призводить до збільшення об'єму фізичної роботи, поліпшенню якості відпочинку, покращенні когнітивної функції почуття відчуття благополуччя і $[6,11,12,15,26,28$, 33].

Роль дієтичного харчування при лікуванні ДЗ/ЗДА $є$ важливою, але необхідно пам'ятати, що із продуктів рослинного всмоктується, лише, 3-5 \% заліза, яке знаходиться в цих продуктах. Це всмоктування залежить від наявності в продуктах факторів, 
які посилюють або послаблюють всмоктування. Призначення до дієти фруктів, соків, які мають велику кількість аскорбінової кислоти, $\epsilon$ обгрунтованим, оскільки, аскорбінова кислота значно покращує всмоктування заліза в кишечнику. При лікуванні ЗДА необхідно обмежити в раціоні харчові продукти, до складу яких входять речовини, які сповільняють всмоктування заліза (фітат, танат, фосфат, оксалат, пектіни, лектіни та інші), які знаходяться у хлібних злаках, висівках, різних зернах, кукурудзі, рисі. 3 цієї ж причини, необхідно обмежити вживання червоного вина (поліфенолати), чаю (танін), молока (кальцій), кави (поліфенолати), а також деякі види мінеральних вод, до складу яких входять карбонат, гідрокарбонат і фосфат [28]. Перевагу в дієті необхідно віддавати продуктам, які багаті на залізо (м'ясо, кров'яні ковбаси, сочевиця, оселедець і т.д.) [34]. В продуктах тваринного походження (яловичина, свинина) залізо знаходиться у формі гему, яке всмоктується найкраще (25$30 \%$ ).

Основний принцип терапії ЗДА полягає в усуненні причин, які спричинили її розвиток, але, у більшості випадків, радикальне усунення причини анемії $\epsilon$ не можливим. В таких клінічних ситуаціях основне значення набуває патогенетична терапія анемії, в першу чергу, призначення залізовмістних препаратів. Пацієнткам із ЗДА $є$ показаним прийом препаратів заліза як з метою корекції анемії, так і з метою поповнення його запасів в організмі [6].

Важливе значення при лікуванні ЗДА має переносимість препаратів заліза. Систематичний огляд [39] 111 досліджень (більше 1000 пацієнтів), після аналізу переносимості пероральних препаратів заліза, встановив що сульфат заліза сухого 247,25 мг, що еквівалентно 80 мг заліза (II) має найнижчий рівень побічних шлунково-кишкових ускладнень (3,7\%) порівняно з іншими препаратами сульфату заліза (30,2\%), залізистим фумаратом (43,4\%) i препаратами, які містять залізо (7\%) Аналогічні результати отримані після аналізу результатів українського багатоцентрового дослідження [40].

Найкращим призначенням є препаратів сульфату заліза з вмістом заліза від 60 до 120 мг. Перевагу має Fe 2+ (краща абсорбція). Препарати заліза призначаються протягом 3-х місяців для поповнення запасів заліза в організмі і лікування ЗДА [7, 10, 30, 35]. Максимальна абсорбція заліза спостерігається на початку лікування: протягом першого тижня всмоктується в середньому до $14 \%$ заліза, через три тижня - 7 \% і тільки 2 \% через чотири місяці.

Препарати заліза розподіляють за їх біодоступністю, ефективністю і частоті виникнення побічних ефектів. Побічні ефекти (частіше всього нудота, закрепи, біль в епігастральної ділянки) пов'язані з контактом великої кількості заліза з слизовою оболонкою шлунка. Саме тому, стандартом феротерапії $\epsilon$ застосування препаратів з повільним виходом заліза. Метою мультицентрового відкритого дослідження [36], в котре було включено 30 невагітних жінок віком від 18 до 45 років 3 ЗДА, було дослідження фармококінетики заліза сульфату сухого 247,25 мг, що еквівалентно 80 мг заліза (II) (лабораторія PierreFabrePharma, Кастр, Франція). Жінки одноразово отримували 2 таблетки заліза сульфату натщесерце. Зразки крові збирали до прийому і через 1, 2, 4, 6, 8, 12 і 24 годин після прийому препарату. Результати показали, що розчинення таблетки заліза сульфату в ШКТ складає 4-6 годин, а концентрація заліза в сироватці крові пацієнтів лишається підвищеною до 12 годин після прийому .

Ефективність сульфату заліза 3 повільним вивільненням заліза була підтверджена i результатами дослідження $P E A R L$ [37], в яке були включені жінки 3 симптоматичними фібромами, рясними місячними кровотечами і ЗДА $(H b<102$ г/л). Пацієнтки були рандомізовані на дві групі: в 1й групі жінки приймали пероральний ulipristal (модулятор рецептору прогестерону) в дозі 510 мг на добу, жінки 2-ї групи отримували плацебо [38] протягом 13 тижнів. Пацієнтки обох груп отримували заліза сульфату сухого 247,25 мг, що еквівалентно 80 мг заліза (II) один раз на добу. Результати дослідження показали, що через 13 тижнів у 90\% жінок 1-ї групи маткові кровотечи зменшилися. Процент пацієнток з нормальним рівнем $\mathrm{Hb}$ (> 120 г/л) збільшився в обох групах $i$ досягнув відповідно 135,0 г / $\mathcal{\Lambda} \pm 1,32$ в групі ulipristal $i$ 126,1 г / $\Omega \pm 1,30$ в групі плацебо. Ці данні свідчать про те, що залізо сульфату відновлює рівень Нb на фоні менструальних кровотеч, які продовжуються. M. Zaim et al. [39] продемонстрували, що здатність заліза сульфату сухого 247,25 мг, що еквівалентно 80 мг заліза (II), але 3 пролонгованим його 
вивільненням, відновлює рівні $\mathrm{Hb}$ у жінок 3 ЗДА також ефективно, як і препарати заліза більш високим вмістом заліза (105 мг). Автори

\section{Висновки}

1. За даними Європейських досліджень виявлено високий ризик розвитку ДЗ/ЗДА у жінок віком 40-55 років при цьому клінічні прояви ЗДА у жінок віком 40-55 років $\epsilon$ проблемою суспільної охорони здоров'я, оскільки призводить не тільки до зниження працездатності, але й до зниження якості життя жінок.

2. Результати проведених досліджень свідчать про багатофакторну структуру причин розвитку ДЗ у жінок віком 40-55 років,

\section{Література}

1. Kassebaum N.J., Jasrasaria R, Naghavi M. et al. A systematic analysis of global anemia burden from 1990 to 2010. Blood 2014. Volume 123. P. 615-624.

2. Nicula R., Costin N. Management of endometrial modifications in perimenopausal women. Clujul Medical journal. 2015. Volume 88. P. 101-110.

3. Beard J., Tobin B. Iron status and exercise. The American Journal of Clinical Nutrition. 2000. Volume 72. P.594-597.

4. Peuranpa. P., Helio.vaara-Peippo S., Fraser I., et al. Effects of anemia and iron deficiency on quality of life in women with heavy menstrual bleeding. Acta Obstet Gynecol Scand. 2014. Volume 93. P. 654-660.

5. Verdon F., Burnand B., Stubi C.L., et al. Iron supplementation for unexplained fatigue in nonanaemic women: double blind randomized placebo controlled trial. British Medical Journal. 2003. Volume 326. P. 1124.

6. Firquet A., Kirschner W., Bitzer J. Forty to fiftyfive-year-old women and iron deficiency: clinical considerations and quality of life. Gynecological Endocrinology. 2017. Volume 33. Issue 7. P. 503-509.

7. World Health Organization [Internet]. Geneva: World Health Organization; 2011 [cited 2017 Feb 02]. Haemoglobin concentrations for the diagnosis of anaemia and assessment of severity. Available from: www.who.int/vmnis/indicators/haemoglobin.pdf.

8. Koo B.B., Bagai K., Walters A.S. Restless legs syndrome: current concepts about disease pathophysiology. Tremor. Other Hyperkinetic. Mov. (NY) 2016. Volume 22. P. 401.

9. Levi M., Rosselli M., Simonetti M., et al. Epidemiology of iron deficiency anaemia in four European countries: a population-based study in primary care. European Journal of Haematology. 2016. Volume 97. P. 583-593.

10. British Columbia Guidelines-Iron deficiency. Vancouver; 2010 [cited 2017 Feb 02]. Available from: http://www2.gov.bc.ca/gov/content/health/practitio ner-professional-resources/bc-guidelines/irondeficiency.

11. Low M.S., Speedy J., Styles C.E., et al. Daily iron supplementation for improving anaemia, iron status пояснювали це кращою абсорбцією мікроелементу.

головними 3 яких $\epsilon$ рясні менструальні крововтрати $(21,1 \%)$, запальні процеси в органах шлунково-кишкового тракту (19,26\%), зниження вживання м'ясних продуктів $(13,76 \%)$, прийоми антикоагулянтів $(10,1 \%)$.

3. Показано, що визначення факторів ризику розвитку анемії i корекції цих негативних проявів за допомогою препаратів заліза є актуальним завданням для лікаря.

and health in menstruating women. Cochrane Database Syst. Rev. 2016. Volume 4: CD009747

12. Murray-Kolb L.E. Iron status and neuropsychological consequences in women of reproductive age: what do we know and where are we headed? The American Journal of Clinical Nutrition. 2011. Volume 141. P. 747-755.

13. Stein J., Connor S., Virgin G., et al. Anemia and iron deficiency in gastrointestinal and liver conditions. World Journal of Gastroenterology. 2016. Volume 22. P. 7908-7925.

14. Saunders A.V., Craig W.J., Baines S.K., et al. Iron and vegetarian diets. The Medical Journal of Australia. 2013. Volume 199. P. 11-16.

15. Wojciak R.W. Effect of short-term food restriction on iron metabolism, relative well-being and depression symptoms in healthy women. Eating and Weight Disorders. 2014. Volume 19. P. 321-327.

16. Dorsey K.A. Menorrhagia, active component service women, U.S. Armed Forces 1998-2012. MSMR. 2013. Volume 20. P. 20-24.

17. Waldmann A., Koschizke J.W., Leitzmann C., et al. Dietary iron intake and iron status of German female vegans: results of the German vegan study. Annals of Nutrition and Metabolism. 2004. Volume 48. P. 103108.

18. Marret H., Fauconnier A., Chabbert-Buffet N., et al. Clinical practice guidelines on menorrhagia: management of abnormal uterine bleeding before menopause. The European Journal of Obstetrics \& Gynecology and Reproductive Biology. 2010. Volume 152. P. 133-137.

19. Santer M, Wyke S, Warner P. What aspects of periods are most bothersome for women reporting heavy menstrual bleeding? Community survey and qualitative study. BMC Womens Health. 2007. Volume 7. P. 8.

20. Matteson K.A., Scott D.M., Raker C.A., et al. The menstrual bleeding questionnaire: development and validation of a comprehensive patient-reported outcome instrument for heavy menstrual bleeding. An International Journal of Obstetrics \& Gynaecology. 2015. Volume 122 P. 681-689. 
21. Munro M.G., Critchley H.O., Broder M.S., et al. FIGO classification system (PALM-COEIN) for causes of abnormal uterine bleeding in nongravid women of reproductive age. International Journal of Gynecology \& Obstetrics. 2011. Volume 113. P. 3-13.

22. NICE [Internet]. London: NICE; 2016 Update [cited 2017 Feb 02]. Heavy menstrual bleeding: assessment and management clinical guideline. Available from: https://www.nice.org.uk/guidance/CG44/chapter/Re commendations\#pharmaceutical-treatments-for-hmb.

23. Galan P., Yoon H.C., Preziosi P., et al. Determining factors in the iron status of adult women in the SU.VI.MAX study. Supplementation en Vitamines et Mine.raux AntioXydants. European Journal of Clinical Nutrition. 1998. Volume 52. P. 383-388.

24. Green B.T., Rockey D.C. Gastrointestinal endoscopic evaluation of premenopausal women with iron deficiency anemia. Journal of Clinical Gastroenterology. 2004. Volume 38. P. 104-109.

25. Hudak L., Jaraisy A., Haj S., et al. An updated systematic review and meta-analysis on the association between Helicobacter pylori infection and iron deficiency anemia. Helicobacter. 2017. Volume 22: e12330. doi: 10.1111/hel.12330.

26. World Health Organization. Guideline: daily iron supplementation in adult women and adolescent girls. Geneva: World Health Organization. 2016.

27. Fashner J., Gitu A.C. Common gastrointestinal symptoms: risks of long-term proton pump inhibitor therapy. FP Essent. 2013. Volume 413. P. 29-39.

28. Coad J., Pedley K. Iron deficiency and iron deficiency anemia in women. Scandinavian Journal of Clinical and Laboratory Investigation. 2014. Volume 244. P. 82-89.

29. Stein J., Connor S., Virgin G., et al. Anemia and iron deficiency in gastrointestinal and liver conditions. World Journal of Gastroenterology. 2016. Volume 22. P. 7908-7925.

30. Goddard A.F., James M.W., McIntyre A.S., et al. Guidelines for the management of iron deficiency anemia. Gut. 2011. Volume 60. P. 1309-1316.

31. Qamar K., Saboor M., Qudsia F., et al. Malabsorption of iron as a cause of iron deficiency

\section{References}

1. Kassebaum N.J., Jasrasaria R, Naghavi M. et al. (2014). A systematic analysis of global anemia burden from 1990 to 2010. Blood, 123, 615-624.

2. Nicula R., Costin N. 2015 (). Management of endometrial modifications in perimenopausal women. Clujul Medical journal, 88, 101-110.

3. Beard J., Tobin B. (2000). Iron status and exercise. The American Journal of Clinical Nutrition, 72, 594-597.

4. Peuranpa. P., Helio.vaara-Peippo S., Fraser I., et al. (2014). Effects of anemia and iron deficiency on quality of life in women with heavy menstrual bleeding. Acta Obstet Gynecol Scand, 93, 654-660.

5. Verdon F., Burnand B., Stubi C.L., et al. (2003). Iron supplementation for unexplained fatigue in nonanaemic women: double blind randomized placebo controlled trial. British Medical Journal, 326, 1124. anemia in postmenopausal women. Journal of Pakistan Medical Association. 2015. Volume 31. P. 304-308.

32. Aigner E, Feldman A, Datz C. Obesity as an emerging risk factor for iron deficiency. Nutrients 2014. Volume 6. P. 3587-3600.

33. Alaunyte I., Stojceska V., Plunkett A. Iron and the female athlete: a review of dietary treatment methods for improving iron status and exercise performance. The Journal of the International Society of Sports Nutrition. 2015. Volume 12. Issue 38. doi: 10.1186/s12970-015-0099-2

34. Cade J.E., Moreton J.A., O'Hara B., et al. Diet and genetic factors associated with iron status in middleaged women. The American Journal of Clinical Nutrition. 2005. Volume 82. P. 813-820.

35. Palacios S. Ferrous versus ferric oral iron formulations for the treatment of iron deficiency: a clinical overview. The Scientific World Journal. 2012. Volume 2012. ID 846824.

36. Leary A., Barthe L., Clavel T., et al. Pharmacokinetics of ferrous sulphate (Tardyferon_) after single oral dose administration in women with iron deficiency anaemia. Drug research (Stuttgart). 2016. Volume 66. P. 51-56.

37. Donnez J., Tatarchuk T.F., Bouchard P., et al. Ulipristal acetate versus placebo for fibroid treatment before surgery. The New England Journal of Medicine. 2012. Volume 366. P. 409-420.

38. Nisolle M., Closon F., Firquet A., et al. Ulipristal acetate (Esmya): a selective modulator of progesterone receptors, new treatment of uterine fibromatosis. Revue Medicale de Liege. 2014. Volume 69. P. 220-225.

39. Zaim M., Piselli L., Fioravanti P., et al. Efficacy and tolerability of a prolonged release ferrous sulphate formulation in iron deficiency anaemia: a noninferiority controlled trial. European Journal of Nutrition. 2012. Volume 51. P. 221-229.

40. Фадеенко Г.Д., Кушнир И.Э. Лечение железодефицитной анемии: клиническая эффективность и безопасность «Тардиферона» (по результатам многоцентрового исследования в Украине). Сучасна гастроентерологія. 2009. № 5. С. 74-80.

6. Firquet A., Kirschner W., Bitzer J. (2017). Forty to fifty-five-year-old women and iron deficiency: clinical considerations and quality of life. Gynecological Endocrinology, 33, 7, 503-509.

7. World Health Organization [Internet]. Geneva: World Health Organization; 2011 [cited 2017 Feb 02]. Haemoglobin concentrations for the diagnosis of anaemia and assessment of severity. Available from: www.who.int/vmnis/indicators/haemoglobin.pdf.

8. Koo B.B., Bagai K., Walters A.S. (2016). Restless legs syndrome: current concepts about disease pathophysiology. Tremor. Other Hyperkinetic. Mov. $(N Y), 22,401$.

9. Levi M., Rosselli M., Simonetti M., et al. (2016). Epidemiology of iron deficiency anaemia in four European countries: a population-based study in 
primary care. European Journal of Haematology, 97, 583-593.

10. British Columbia Guidelines-Iron deficiency. Vancouver; 2010 [cited 2017 Feb 02]. Available from: http://www2.gov.bc.ca/gov/content/health/practitio ner-professional-resources/bc-guidelines/irondeficiency.

11. Low M.S., Speedy J., Styles C.E., et al. (2016). Daily iron supplementation for improving anaemia, iron status and health in menstruating women. Cochrane Database Syst. Rev, 4, CD009747

12. Murray-Kolb L.E. (2011). Iron status and neuropsychological consequences in women of reproductive age: what do we know and where are we headed? The American Journal of Clinical Nutrition, 141, 747-755.

13. Stein J., Connor S., Virgin G., et al. (2016). Anemia and iron deficiency in gastrointestinal and liver conditions. World Journal of Gastroenterology, 22, 7908-7925.

14. Saunders A.V., Craig W.J., Baines S.K., et al. (2013). Iron and vegetarian diets. The Medical Journal of Australia, 199, 11-16.

15. Wojciak R.W. (2014). Effect of short-term food restriction on iron metabolism, relative well-being and depression symptoms in healthy women. Eating and Weight Disorders, 19, 321-327.

16. Dorsey K.A. (2013). Menorrhagia, active component service women, U.S. Armed Forces 19982012. MSMR, 20, 20-24.

17. Waldmann A., Koschizke J.W., Leitzmann C., et al. (2004). Dietary iron intake and iron status of German female vegans: results of the German vegan study. Annals of Nutrition and Metabolism, 48, 103-108.

18. Marret H., Fauconnier A., Chabbert-Buffet N., et al. (2010). Clinical practice guidelines on menorrhagia: management of abnormal uterine bleeding before menopause. The European Journal of Obstetrics \& Gynecology and Reproductive Biology, 152, 133-137.

19. Santer M, Wyke S, Warner P. (2007). What aspects of periods are most bothersome for women reporting heavy menstrual bleeding? Community survey and qualitative study. BMC Womens Health, 7, 8.

20. Matteson K.A., Scott D.M., Raker C.A., et al. (2015). The menstrual bleeding questionnaire: development and validation of a comprehensive patient-reported outcome instrument for heavy menstrual bleeding. An International Journal of Obstetrics \& Gynaecology, 122, 681-689.

21. Munro M.G., Critchley H.O., Broder M.S., et al. (2011). FIGO classification system (PALM-COEIN) for causes of abnormal uterine bleeding in nongravid women of reproductive age. International Journal of Gynecology \& Obstetrics, 113, 3-13.

22. NICE [Internet]. London: NICE; 2016 Update [cited 2017 Feb 02]. Heavy menstrual bleeding: assessment and management clinical guideline. Available from: https://www.nice.org.uk/guidance/CG44/chapter/Re commendations\#pharmaceutical-treatments-for-hmb.
23. Galan P., Yoon H.C., Preziosi P., et al. (1998). Determining factors in the iron status of adult women in the SU.VI.MAX study. Supplementation en Vitamines et Mine.raux AntioXydants. European Journal of Clinical Nutrition, 52, 383-388.

24. Green B.T., Rockey D.C. (2004) Gastrointestinal endoscopic evaluation of premenopausal women with iron deficiency anemia. Journal of Clinical Gastroenterology, 38, 104-109.

25. Hudak L., Jaraisy A., Haj S., et al. (2017). An updated systematic review and meta-analysis on the association between Helicobacter pylori infection and iron deficiency anemia. Helicobacter, 22, e12330. doi: 10.1111/hel.12330.

26. World Health Organization. Guideline: daily iron supplementation in adult women and adolescent girls. Geneva: World Health Organization. 2016.

27. Fashner J., Gitu A.C. (2013). Common gastrointestinal symptoms: risks of long-term proton pump inhibitor therapy. FP Essent, 413, 29-39.

28. Coad J., Pedley K. (2014). Iron deficiency and iron deficiency anemia in women. Scandinavian Journal of Clinical and Laboratory Investigation, 244, 82-89.

29. Stein J., Connor S., Virgin G., et al. (2016). Anemia and iron deficiency in gastrointestinal and liver conditions. World Journal of Gastroenterology, 22, 7908-7925.

30. Goddard A.F., James M.W., McIntyre A.S., et al. (2011). Guidelines for the management of iron deficiency anemia. Gut, 60, 1309-1316.

31. Qamar K., Saboor M., Qudsia F., et al. (2015). Malabsorption of iron as a cause of iron deficiency anemia in postmenopausal women. Journal of Pakistan Medical Association, 31, 304-308.

32. Aigner E, Feldman A, Datz C. (2014). Obesity as an emerging risk factor for iron deficiency. Nutrients, 6 , 3587-3600.

33. Alaunyte I., Stojceska V., Plunkett A. (2015). Iron and the female athlete: a review of dietary treatment methods for improving iron status and exercise performance. The Journal of the International Society of Sports Nutrition, 12, 38, doi: 10.1186/s12970-015-0099-2

34. Cade J.E., Moreton J.A., O'Hara B., et al. (2005). Diet and genetic factors associated with iron status in middle-aged women. The American Journal of Clinical Nutrition, 82, 813-820.

35. Palacios S. (2012). Ferrous versus ferric oral iron formulations for the treatment of iron deficiency: a clinical overview. The Scientific World Journal, 2012. ID 846824.

36. Leary A., Barthe L., Clavel T., et al. (2016). Pharmacokinetics of ferrous sulphate (Tardyferon_) after single oral dose administration in women with iron deficiency anaemia. Drug research (Stuttgart), 66, 51-56.

37. Donnez J., Tatarchuk T.F., Bouchard P., et al. (2012). Ulipristal acetate versus placebo for fibroid treatment before surgery. The New England Journal of Medicine, 366, 409-420. 
38. Nisolle M., Closon F., Firquet A., et al. (2014). Ulipristal acetate (Esmya): a selective modulator of progesterone receptors, new treatment of uterine fibromatosis. Revue Medicale de Liege, 69, 220-225.

39. Zaim M., Piselli L., Fioravanti P., et al. (2012). Efficacy and tolerability of a prolonged release ferrous sulphate formulation in iron deficiency anaemia: a non- inferiority controlled trial. European Journal of Nutrition, 51, 221-229.

40. Fadeenko G.D., Kushnir I.E. (2009). Treatment of iron deficiency anemia: clinical efficacy and safety of tardyferon. Results of a Multicenter Study Conducted in Ukraine. Suchasna Gastroenterologia, 5, 74-80.

\title{
ОСОБЕННОСТИ КЛИНИЧЕСКОГО ТЕЧЕНИЯ ЖЕЛЕЗОДЕФИЦИТНОЙ АНЕМИИ У ЖЕНЩИН 40 - 55 ЛЕТ
}

\section{С.А. Гусева ${ }^{1}$, Я.Б Савченко ${ }^{2}$}

\author{
1 Украинська военно-медицинская академия, г. Киев, Украина \\ ${ }^{2}$ Национальний военно-медицинский клинический центр «ГВКГ», г. Киев, Украина
}

Вступление. Дефицит железа (ДЗ) является серьезной проблемой у женщин в возрасте 40 - 55 лет. B этот период происходит вариации гормональных уровней, нарушение менструального цикла с риском возникновения тяжелой кровопотери. Кроме того, женщины этой возрастной группы часто ведут нездоровый образ жизни, с последующим развитием нарушений, приводящих к изменениям в физическом и психическом состояниях.

Цель работы. Исследовать причины развития ЖДА у женщин, которые находились под наблюдением в клинике гематологии Национального военного медицинского клинического центра «Главный военный клинический госпиталь» МО Украины и определить факторы риска развития анемии и ее коррекции.

Материалы и методы. В статье предоставлены данные европейских исследований высокий риск развития дефицита железа / железодефицитной анемии (ДЗ / ЖДА) у женщин в возрасте 40 - 55 лет. Проведенный анализ обследования и лечения 109 женщин, которые находились под наблюдением в клинике гематологии Национального военно-медицинском клиническом центре «ГВКГ» (2. Киев) с 2015 по 2019 годы.

Результаты. Обобщены современные научные европейские исследования риска развития ЖД/ ЖДА у женщин в возрасте 40-55 лет. Проведен анализ причин развития ЖД / ЖДА по результатам обследования и лечения женщин, которые находились под наблюдением в клинике гематологии Национального военномедицинском клиническом центре «ГВКГ» (2. Киев) с 2015 по 2019 годы. Выделены наиболее частые причины развития ЖД / ЖДА: обильные менструальные кровопотери, воспалительные процессы в органах желудочно-кишечного тракта, снижение потребления мясных продуктов, приемы антикоагулянтов, нарушение диеты с целью похудения, что в целом составляет 75\% среди возможных причин.

Выводы. По данным европейских исследований выявлен высокий риск развития ЖД / ЖДА у женщин в возрасте 40-55 лет при этом клинические проявления ЖДА у женщин в возрасте 40-55 лет является проблемой общественного здравоохранения, поскольку приводит не только к снижению работоспособности, но и к снижению качества жизни женщин. Результаты проведенных исследований свидетельствуют о многофакторную структуру причин развития ЖДА у женщин в возрасте 40-55 лет, главными из которых являются обильные менструальные кровопотери (21,1\%), воспалительные процессы в органах желудочно-кишечного тракта (19,26\%), снижение употребления г. мясных продуктов (13,76\%), приемы антикоагулянтов (10,1\%). Показано, что определение факторов риска развития анемии и коррекции этих негативных проявлений с помощью препаратов железа является актуальной задачей для врача.

Ключевые слова: женщины 40-55 лет, дефицит железа, железодефицитная анемия, причины развития, терапия.

\section{SPECIFICS OF THE CLINICAL COURSE OF IRON DEFICIENCY ANEMIA AMONG WOMEN AGED 40-55 YEARS}

\author{
S.A. Guseva1, Ya. B. Savchenko² \\ ${ }^{1}$ Ukrainian Military Medical Academy, Kyiv, Ukraine \\ ${ }^{2}$ National Military Medical Clinical Center «Main Military Clinical Hospital», Kyiv, Ukraine
}

Introduction. Iron deficiency (ID) is a serious problem in women aged 40-55 years. During this period there are variations in hormonal levels, menstrual irregularities with the risk of severe blood loss. In addition, women in this age group often lead unhealthy lifestyles, followed by the development of disorders that lead to changes in physical and mental states.

The purpose: to determine the causes of iron deficiency anemia in women who were under observation in the hematology clinic of the National Military Medical Clinical Center «Main Military Clinical Hospital» of the Ministry of Defense of Ukraine and identify risk factors for anemia and its correction. 
Materials and methods. The article presents data from European studies on the high risk of developing iron deficiency / iron deficiency anemia (IDA) in women aged 40-55 years. The analysis of examination and treatment of 109 women who were under observation in the hematology clinic of the National Military Medical Clinical Center «GVKG» (Kyiv) from 2015 to 2019.

Results. Modern European scientific research on the risk of developing ID / IDA in women aged 40-55 years is summarized. An analysis of the causes of IDA in women based on the results of examination and treatment of women who were under observation in the hematology clinic of the National Military Medical Clinical Center «GVKG» (Kyiv) from 2015 to 2019. The most common causes of ID / IDA are: heavy menstrual blood loss, inflammatory processes in the gastrointestinal tract, reduced consumption of meat products, anticoagulants, dietary disorders for weight loss, which is generally $75 \%$ of the possible causes.

Conclusions. According to European studies, there is a high risk of developing ID / IDA in women aged 40-55 years, while the clinical manifestations of IDA in women aged 40-55 years is a public health problem, as it leads not only to reduced efficiency but also to reduced quality of women life. The results of the studies indicate a multifactorial structure of the causes of IDA in women aged 40-55 years, the main of which are abundant menstrual blood loss (21.1\%), inflammatory processes in the gastrointestinal tract (19.26\%), reduced use of meat products (13.76\%), anticoagulants (10.1\%). It is shown that determining the risk factors for the development of anemia and the correction of these negative manifestations with the help of iron supplements is an urgent task for the doctor.

Key words: women aged 40-55 years, iron deficiency, iron deficiency anemia, causes of development, therapy.

Конфлікт інтересів: відсутній.

Conflicts of interest: authors have no conflict of interest to declare.

\section{Відомості про авторів:}

Гусєва С.А.А,B,C,D,E,F - доктор медичних наук, професор, професор кафедри військової терапії Української військово-медичної академії, м. Київ E-mail: gushem@ukr.net

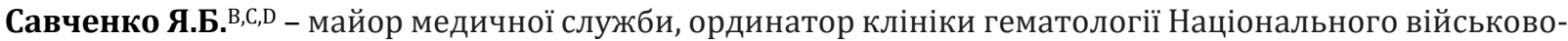
медичного клінічного центру «Головний військовий клінічний госпіталь» м. Київ Е-mail: 87yaruna@gmail.com

$A$ - концепція та дизайн дослідження; $B$ - збір даних; $C$ - аналіз та інтерпретація даних;

$D$ - написання статmi; $E$ - редагування статmi; F- остаточне затвердження статті.

\section{Сведения об авторах:}

Гусева С.А. - доктор медицинских наук, профессор, профессор кафедры военной терапии Украинской военно-медицинской академии., г. Киев E-mail: gushem@ukr.net

Савченко Я.Б. - майор медицинской службы, ординатор клиники гематологии Национального военно-медицинского клинического центра «Главный военный клинический госпиталь» г. Киев Е-таil: 87yaruna@gmail.com

\section{Information about authors:}

Guseva S.A. A,B,C,D,E,F - Doctor of Medical Sciences, Professor, Professor of department of Military Therary of the Ukrainian Military Medical Academy, Kyiv, Ukraine. E-mail: gushem@ukr.net

Savchenko Ya. B. ${ }^{B, C, D}$ - Major MS, resident of the hematology clinic of the National Military Medical Clinical Center «Main Military Clinical Hospital» Kyiv E-mail: 87yaruna@gmail.com

$A$ - research concept and design; $B$ - collection and/or assembly of data; $C$ - data analysis and interpretation;

$D$ - writing the article; $E$ - critical revision of the article; $F$ - final approval of the article.

Адреса для листування: вул. Московська, 45/1, буд. 33, м. Київ 01015 